\title{
ASSESSMENT OF HYDROCHEMICAL QUALITY OF GROUND WATER UNDER SOME URBAN AREAS WITHIN SANA'A SECRETERIAT
}

\author{
AL-Ariqi, Wadie S. $T^{*}$ and Ghaleb, Abduljalil A.D.S $S^{2}$ \\ 'Chemistry Department, Faculty of Science, Sana'a University \\ 'Food Scie. \& Tech. Department, Faculty of Agric., Sana'a University \\ P.O. Box 12364 Sana'a Republic of Yemen \\ *ariqui@maktoob.com
}

\begin{abstract}
Groundwater from nine wells of three different districts, located at Sana'a secretariat was analyzed for hydrochemical quality assessment. Measurements of water quality parameters including $\mathrm{pH}, \mathrm{EC}, \mathrm{CO}^{2-}, \mathrm{HCO}_{3}^{-}, \mathrm{Cl}^{-}, \mathrm{NO}_{3}^{-}, \mathrm{SO}^{2-}, \mathrm{Ca}^{2+}, \mathrm{Mg}^{2+}, \mathrm{Fe}^{3+}, \mathrm{K}^{+}$, and $\mathrm{Na}^{+}$were carried out . Classification of the groundwater samples according to $\mathrm{Cl}, \mathrm{SO}_{4}^{2-}, \mathrm{CO}_{3}{ }^{2-}$ and $\mathrm{HCO}_{3}^{-}$, hardout . Classification of the groundwater samples according to $\mathrm{Cl}, \mathrm{SO}_{4}{ }^{2-}, \mathrm{CO}_{3}{ }^{2-}$ and $\mathrm{HCO}_{3}$, hardness (H), total dissolved solids (TDS), base-exchange, and meteoric genesis was demonstrated.
Suitability of ground water samples for irrigation and industrial uses according to sodium Suitability of ground water samples for irrigation and industrial uses according to sodium
adsorption ration (SAR), ratio of dissolved sodium (RDS), residual sodium carbonate (RSC) and saturation index (SI) was also investigated. The results of this study showed that almost all ground water samples were of good quality that makes them suitable for drinking and domestic uses. Results also indicated that even though some of the ground water samples were suitable for irrigation purposes, almost all of them were found not be good for industrial uses. Despite all drawbacks of the sewerage system built around Sana' a secretariat at the beginning of the first decade of the third millennium, the results of this study indicat significant improvement in Sana'a secretariat ground water quality.
\end{abstract}

\section{INTODUCTION}

Groundwater is an important source of water supply in many parts of the world. In Yemen, groundwater is considered as the main wate source for drinking, domestic uses and irrigation purposes. Sana' a secretariat is one of the 22 governorates that comprise the Republic of Yemen. According to the current Yemeni local administrative dividing system, there are 12 districts in Sana' a secretariat, most of which are classified to be urban. Though there are tremendous increases in areal expansion and population growth in
Sana'a secretariat, groundwater wells, with no other considerable alternatives are still being used as a source of water supply for drinking and othe purposes.

Quality of groundwater depends, to some extents, on its chemical composition. Cation and anions play important roles as indicators of groundwater contamination (Chgue'-Goff, et., al., 1997; Sultan, 1998; Foppen, 2002; Matthiesen, 2008). Source of contamination are different, however wastewater represents one of the most important one, especially when sewerage system is not available. The Urban Water Supply and Sanito (UWSS) sub-secon Wan ted in 1997. Sin-sector reform in Yemen sta- 
UWSS has covered 95 percent of the urban population and has improved its standards of delivery tremendously. Previous research on groundwater quality and drinking water supply between 1995 and 2000 has been carried out in Sana'a secretariat (Foppen, et. al., 2005), however ground water as an essential resource in Yemen shall regularly be monitored to ensure its protection from contamimonitored to ensure its protection from contami-
nation. The present study focused on assessment of hydrochemical quality of ground water samples collected from wells located in three district of Sana'a secretariat, to compare the results with the different standards and to illustrate ground water suitability for utilizations in drinking, irrigation and industrial purposes through the calculation of some indices.

\section{MATERIALS AND METHODS}

\section{Site of wells}

Groundwater samples were collected form nine wells located in three districts of Sana'a sedium, within $\boldsymbol{A L}$-Tahreer district. Wells no, sta6, 7, 8 and 9 located at Adhban, Tayseer, 22 May, Bin Maged, AL-Zubairy, AL-Baladiah zones respectively, within $\boldsymbol{A L}$-Wahdah district and wells noc 2,3 located at Shamlan and Asser zones respectively, within Maeen district.

\section{Sampling}

Groundwater samples were taken in 2003, 2004 from nine drilled wells located at the three different districts, as mentioned here above, where $\boldsymbol{A L}$-Tahreer is considered as part of the city center, but $\boldsymbol{A L}$-Wahdah and Maeen tend to be as part of the zone located in the western part of the sewered area of Sana'a secretariat, as indicated by Foppen, (2002). Submersible pumps were used to draw the samples into 2.5 letter acid-washed polyethylene bottles, which were thoroughly rinsed several times with distilled water, followed with a portion of the water sample prior to sampling. Samples were immediately cooled at $4^{\circ} \mathrm{C}$ using portable icebox and transported to the laboratory, where they were analyzed within 48 hours maximum.

\section{Measurements and analyses:}

All chemicals used in this study were of analytical grade and purchased from local distributors of BDH and Sigma companies in Yemen. The various parameters were determined according to the procedures stated in the American $\mathrm{Pu}$ blic Health Association (APHA), standard methods for the examination of water and wastewater (1998).

\section{Indices of calculations}

Sodium adsorption ration (SAR), ratio of dissolved sodium (RDS) and residual sodium carbonate (RSC) indices were calculated according to formulae stated by Eaton, F.M., 1950, and lately used by Shaki and Adeloye, (2006), while saturation index (SI) was calculated according to formula stated by Soltan (1998).

\section{RESULTS AND DISCUSSION}

1. Physical and Chemical Properties of the Ground Water Samples

Mean values of the various parameters determined in the ground water samples drawn from the nine wells located at the three different districts, namely: Macts, namely. AL-Tahreer, AL-Wahdah and Maeen, located in Sana' a secretariat, are shown
in table (1).
Table 1. Mean values of physical and chemical parameters of ground water samples drawn from wells located at different districts in Sana'a secretariat.

\begin{tabular}{|c|c|c|c|c|c|c|c|c|c|c|c|c|c|}
\hline & \multirow{2}{*}{$\begin{array}{c}\mathrm{pH} \\
\left(20^{\circ} \mathrm{C}\right)\end{array}$} & \multirow{2}{*}{$\begin{array}{c}\text { E.C. } \\
\mu \mathrm{S} / \mathrm{cm}\end{array}$} & \multicolumn{10}{|c|}{ Anions and Cations $(\mathrm{mg} / \mathrm{L})$} \\
\hline & & & & $\mathrm{CO}_{3}^{2-}$ & $\mathrm{HCO}_{3}^{-}$ & $\mathrm{Cl}^{-}$ & $\mathrm{NO}_{3}^{-}$ & $\mathrm{SO}_{4}^{2-}$ & $\mathrm{Ca}^{2+}$ & $\mathrm{Mg}^{2+}$ & $\mathrm{Fe}^{3+}$ & $\mathrm{K}^{+}$ & $\mathrm{Na}^{+}$ \\
\hline \multicolumn{2}{|c|}{$\begin{array}{l}\text { Al-Durafi stadium } \\
\text { (Well No. 1) }\end{array}$} & 6.86 & 1807 & Nil & 249 & 310 & 40 & 185 & 269 & 38 & 0.13 & 3.3 & 38 \\
\hline \multicolumn{2}{|c|}{$\begin{array}{l}\text { Shamlan area } \\
\text { (Well No. 2) }\end{array}$} & 7.13 & 577 & Nil & 234 & 44 & 5.3 & 65 & 48 & 17.5 & $0.15^{*}$ & 4.2 & 44 \\
\hline \multicolumn{2}{|c|}{$\begin{array}{l}\text { Asser area } \\
\text { (Well No. 3) }\end{array}$} & 8.11 & 626 & Nil & 244 & 50 & 4 & 70 & 17.6 & 9.7 & 0.03 & 6.3 & 103 \\
\hline \multicolumn{2}{|c|}{$\begin{array}{l}\text { Adhban area } \\
\text { (Well No. 4) }\end{array}$} & 7.51 & 410 & Nil & 239 & 22 & 4.4 & 35 & 38.5 & 7 & 0.98 & 4.21 & 56 \\
\hline \multicolumn{2}{|c|}{$\begin{array}{l}\text { Al-tahreer } \\
\text { (Well No. 5) }\end{array}$} & 8.36 & 566 & Nil & 220 & 75 & 6.6 & 40 & 19 & 12 & 0.02 & 4.5 & 92 \\
\hline \multicolumn{2}{|c|}{$\begin{array}{l}22 \text { May area } \\
\text { (Well No. 6) }\end{array}$} & 7.28 & 660 & Nil & 239 & 108 & 7.8 & 45 & 109 & 21 & 0.01 & 2.2 & 30 \\
\hline \multicolumn{2}{|c|}{$\begin{array}{l}\text { Bin maged } \\
\text { (Well No. 7) }\end{array}$} & 8.78 & 447 & Nil & 102 & 56 & 4.4 & 32.5 & 6.5 & 0.91 & 0.00 & 0.5 & 96 \\
\hline \multicolumn{2}{|c|}{$\begin{array}{l}\text { Al-zubairy Garden } \\
\text { (Well No. 8) }\end{array}$} & 9.45 & 494 & 4.8 & 137 & 68 & 12 & 28 & 11 & 6.8 & 0.01 & 1.4 & 91 \\
\hline \multicolumn{2}{|c|}{$\begin{array}{l}\text { Al-baladiah area } \\
\text { (Well No. 9) }\end{array}$} & 9.40 & 507 & 29 & 107 & 45 & 22 & 60 & 3.2 & 2.9 & 0.22 & 0.6 & 119 \\
\hline \multicolumn{2}{|c|}{ WHO Limits } & $6.5-8.5$ & - & - & - & 250 & 50 & 500 & - & - & 0.30 & - & 200 \\
\hline \multirow[b]{2}{*}{$\begin{array}{l}\text { Yemeni } \\
\text { Limits }\end{array}$} & $\begin{array}{c}\text { Optimal } \\
\text { Level }\end{array}$ & $6.5-8.5$ & $450-1000$ & - & 150 & 200 & 10 & 200 & 75 & 30 & 0.30 & 8 & 200 \\
\hline & $\begin{array}{l}\text { Highest } \\
\text { Permissible } \\
\text { Level }\end{array}$ & $6.5-9$ & 2500 & - & 500 & 600 & 50 & 400 & 200 & $\begin{array}{c}30 \\
-150\end{array}$ & 1 & 12 & 400 \\
\hline
\end{tabular}

Each value of the determined parameter represents a mean of three measurements.

Nil, means not detectable.

$(-)$, means not available.

The $\mathrm{pH}$ mean values of ground water samples determined for this study were in the range of 6.86-9.45, (lowest in well no. 1 and highest in well no. 8). The $\mathrm{pH}$ mean value $(6.86)$, seems to be in agreement agreent regarding $\mathrm{pH}$ decrease of ground water samples obtained from wells located in a part of Sana' secretariat that has been developed between 1975 and 1995, because well no. 1, in Al-durafi stadium is located within this part of Sana'a secretariat. $\mathrm{pH}$ mean values of samples collected from wells no. 2 and 3 of Maeen district and wells no (4-9) o $\boldsymbol{A L}$-Wahdah district were ranged from 7.3 to 9.45 . This result also goes along with that indicated by Foppen, J., (2002) in his model for ground wate in depth of more than $150 \mathrm{~m}$ in the aquifer below Sana' a secretariat, five years after the year 2000.

Location of these two districts within the western part of Sana'a secretariat, where pit latrines are still very common might be an appropriate reason to be used as a justification for considering such $\mathrm{pH}$ mean values are relatively comparable with that indicated by Foppen's model. The range of electrical conductivity (EC), was 410 to 1807 $\mu$ simens $/ \mathrm{cm}$, (highest in well no. 1 and lowest in well no. 4). Although EC values of the ground water samples of this study are related to those of total dissolved solids (TDS), shown in table (2) here below, the EC values were all, except that of well no. (1) came within the optimal range levels specified in the Yemeni standard.

Chloride $\left[\mathrm{Cl}^{-}\right]$of the ground water samples was found in the range $22-310 \mathrm{mg} / \mathrm{L}$, (highest in well no. 1 and lowest in well no. 4). Considering 
that $\left[\mathrm{Cl}^{-}\right]$is a major indicator that might be used to infer infiltration of waste water from cesspits into ground water (Foppen, J., 2002), and as it can be noted from table (1), $\left[\mathrm{Cl}^{-}\right]$in ground water sample collected from well no. 1 was approximately equal to $9 \mathrm{mmol} / \mathrm{L}$. Such mean value is considerably high and relatively comparable to the higher limit of [Cl-], reported by Foppen, J., (2002) in ground water samples collected from wells located at the center and northern part below Sana'a secretariat. Ground water sample of well no. 1, located at Aldurafi stadium in $\boldsymbol{A L}$-Tahreer district within the city center area is thus very likely contaminated with waste water that might be infiltrate into it from surrounded cesspits. This inference might be supported [ $\mathrm{NO}_{3}^{-}$, elaborated within the same table, where it is noted that $\left[\mathrm{NO}_{3}^{-}\right]$in the ground water samples ranges from $4-40 \mathrm{mg} / \mathrm{L}$, (highest in well no. 1 also). However, $\left[\mathrm{NO}_{3}^{-}\right]$in well no. 1 , as $40 \mathrm{mg} / \mathrm{L}(0.64 \mathrm{mmol} / \mathrm{L})$ was fairly below the lower limit of range 1 to $3 \mathrm{mmol} / \mathrm{L}$ in ground water samples of aquifer below Sana' a secretariat, as reported by Foppen, J., (2002). Yet Fetouani, S. et al.,(2008) indicated that ground water is considered contaminated with waste water, when its [NO-] exceds $0.13 \mathrm{mg} / \mathrm{L}$ according to $10 \mathrm{ph}$. posed by the WHO for drinking water. While west levels of sulphae $\left[\mathrm{SO}_{4}^{2-}\right]$ in well no. 8 , as 28 $\mathrm{mg} / \mathrm{L}$, the highest level of the $\left[\mathrm{SO}_{4}{ }^{2-}\right]$ was found in $\mathrm{mg} / \mathrm{L}$, the highest level of
well no. 1 as $185 \mathrm{mg} / \mathrm{L}$.

The highest calcium concentration $\left[\mathrm{Ca}^{2+}\right]$ was found in ground water sample of well no. 1 , as $269 \mathrm{mg} / \mathrm{L}$ and the lowest, in ground water sample of well no. 9 , as $3.2 \mathrm{mg} / \mathrm{L}$. Though $\left[\mathrm{Ca}^{2+}\right]$ of ground water sample collected from well no. was beyond the higher Yemeni permissible limit, none of the other ground water samples analyzed in this study for $\left[\mathrm{Ca}^{2+}\right]$, however exceed init. limit. Magnesium concentration $\left[\mathrm{Mg}^{2+}\right]$ in the ground water samples were in the range of 2.9 and $38 \mathrm{mg} / \mathrm{L}$. The lowest and the highest were in well no. 9 and well no. 1 respectively, but even in well no. $1\left[\mathrm{Mg}^{2+}\right]$ was within the range limits $(30-150 \mathrm{mg} / \mathrm{L})$, stated in the Yemeni permissible level. Iron concentrations $\left[\mathrm{Fe}^{3+}\right]$ in ground water samples range from zero to $0.98 \mathrm{mg} / \mathrm{L}$, and none of the samples analyzed for iron in this study exceeded the permissible limits of the WHO and Yemen. Mean values of potas ${ }^{\left.-\mathrm{K}^{+}\right]}$and and Yenc [Nes 0.5-6.3  gh ground water samples collected from well no. 3, located in Maeen district, were of the highes in concentrations of both potassium and sodium, ground water samples collected from wells no. 6 and 7 were of the lowest concentrations of the two cations. Yet, wells no. 6 and 7 are located in $\boldsymbol{A L}$ Wahdah district.

2-Classification of the ground water samples according to different criteria:

Classification of the water ground samples that were under investigation for this study is demonstrated in table (2).

Table (2). Classification of ground water samples according to different criteria.

\begin{tabular}{|c|c|c|c|c|c|c|c|c|c|c|c|c|c|c|}
\hline \multirow[b]{2}{*}{$\begin{array}{c}\text { Well } \\
\text { Site \& No. }\end{array}$} & \multicolumn{2}{|c|}{$\mathrm{Cl}^{-}$} & \multicolumn{2}{|c|}{$\mathrm{HCO}_{3}+\mathrm{CO}_{3}^{2-}$} & \multicolumn{2}{|c|}{$\mathrm{SO}_{4}^{2}$} & \multicolumn{2}{|c|}{ Hardness } & \multicolumn{2}{|c|}{$\begin{array}{c}\text { TDS } \\
\left(103^{\circ} \mathrm{C}\right)\end{array}$} & \multicolumn{2}{|c|}{$\begin{array}{c}\text { Base } \\
\text { exchange* }\end{array}$} & \multicolumn{2}{|c|}{ Met.genesis } \\
\hline & meq/1 & Class & meq/1 & Class & meq/1 & Class & meq/1 & Class & $\mathrm{mg} / \mathrm{l}$ & Class & meq/l & Class & meq/l & Class \\
\hline $\begin{array}{l}\text { 1-Durafi stadium } \\
\text { (Well No.1) }\end{array}$ & 8.73 & normal & 4.08 & normal & 3.9 & normal & 16.67 & & 1175 & brackish & $<1$ & A & $<1$ & deep \\
\hline $\begin{array}{l}\text { Shamlan area } \\
\text { (Well No.2) }\end{array}$ & 1.24 & normal & 3.84 & normal & 1.35 & normal & 3.86 & $\begin{array}{l}\text { Mod. } \\
\text { Hard }\end{array}$ & 375 & fresh & $<1$ & A & $<1$ & leep \\
\hline $\begin{array}{l}\text { Asser area } \\
\text { (Well No.3) }\end{array}$ & 1.41 & normal & 4 & normal & 1.46 & normal & 1.69 & Soft & 304 & fresh & $>1$ & B & $>1$ & surface \\
\hline $\begin{array}{l}\text { Adhban aeria } \\
\text { (Well No.4) }\end{array}$ & 0.62 & normal & 3.92 & normal & 0.73 & normal & 2.51 & $\begin{array}{l}\text { Mod. } \\
\text { Soft }\end{array}$ & 267 & fresh & $>1$ & B & $>1$ & surtact \\
\hline $\begin{array}{l}\text { Al-tayseer } \\
\text { (Well No.5) }\end{array}$ & 2.11 & normal & 3.61 & normal & 3 & imal & 1.95 & Soft & 275 & fresh & $>1$ & B & $>1$ & surface \\
\hline $\begin{array}{l}22 \text { may area } \\
\text { (Well No.6) }\end{array}$ & 3.04 & normal & 3.92 & norma & 0.94 & rmal & 7.2 & $\begin{array}{l}\text { Mod. } \\
\text { Hard }\end{array}$ & 429 & fresh & $<1$ & A & $<1$ & deep \\
\hline Bin Maged & 1.58 & normal & 1.67 & normal & 0.68 & normal & 0.41 & Soft & 291 & fresh & $>1$ & B & $>1$ & rface \\
\hline $\begin{array}{r}\text { Alzubairy g } \\
\text { (Well No }\end{array}$ & 1.92 & normal & 2.41 & normal & 0.58 & normal & 1.12 & Soft & 239 & fresh & $>1$ & B & $>1$ & surfa \\
\hline $\begin{array}{l}\text { Albaldiah } \\
\text { (Well N }\end{array}$ & 1.27 & normal & 2.72 & normal & 1.25 & normal & 0.4 & Soft & 330 & fresh & $>1$ & B & $>1$ & surfac \\
\hline
\end{tabular}

* Base exchange, $=\frac{\mathrm{Na}^{+}-\mathrm{Cl}^{-}}{\mathrm{SO}^{2-}}$ meqlL $\mathrm{A}=\mathrm{Na}-\mathrm{SO}_{4}$ type,$\quad \mathrm{B}=\mathrm{Na}-\mathrm{HCO}_{3}$ type

It is apparent from the table that the concentrations of $\mathrm{Cl}^{-}, \mathrm{SO}_{4}^{2-}, \mathrm{HCO}_{3+}^{-} \mathrm{CO}_{3}{ }^{2-}$ in all samples were found to be $<15 \mathrm{meq} / \mathrm{L},<6 \mathrm{meq} / \mathrm{L}$, an $(2-7 \mathrm{meq} / \mathrm{L})$ respectively. Hence and according to the American Public Health Association (1992) ride, normal sulphate and normal carbonate and ride, normal sulphate and normal carbonate and bicarbonate. Depending on mean values reflec-
ting degree of hardness in table (2) and according to classification of ground water proposed by Klimentov, (1983), the ground water samples of the wells no. (2 and 5) are considered moderately hard, while that the well no. (1) is very hard, but those of the wells no $(3,5,7,8$ and 9$)$ are soft, and that of the well and the of the well no. (4) is, it can be noted from table (2), the ranges of total dissolved solids (TDS) were 239 to $1175 \mathrm{mg} / \mathrm{L}$, (highest in well no. I and lowest in well no. 8). In other words, the TDS mean values of all groun water samples, except that of well no. (1), were below the optimal value (650) defined within the Yemeni standards, and they were far below the lower limit (1000), specified in the WHO standards. Hence, ground water samples of the wells no. $(2$, $3,4,5,6,7,8,9)$, when the criteria specified by Davis, and De Wiest, (1967) is considered, would be classified as fresh, however that of the well no. (1), would be brackish.

According to the base exchange values, calculated based on the formula proposed by Matthess, (1982) and shown below table (2), the predominate water type of samples, drawn from well no. $(1,2$, and 6$)$ in, located in Al-Durafi stadium, Shamlan area and 22 May area respectively, are $\mathrm{Na}-\mathrm{SO}_{4}$ while $\mathrm{Na}-\mathrm{HCO}_{3}$ water type is predy, a te in the other samples drown from well located in Adban, AL-Tayser, Bin Maged, AL-Zubiry Garden and Albaldiah areas. Ground water samples drawn from drawn from well no. (1,2, and 6) in, located in
Al-Durafi stadium, Shamlan area and 22 May area 
respectively, were classified to be deep meteoric water percolation type, and those of well no. $(3,4,5,7$, $8, \& 9)$ were classified as surface and shallow meteoric water percolation type. Such classification was judged based on the values of hydrochemical parameters $\mathrm{rK} / \mathrm{Cl}, \mathrm{rNa} / \mathrm{rCl}, \mathrm{rMg} / \mathrm{rCl}, \mathrm{rCa} / \mathrm{rCl}$, and $\mathrm{rSO} / \mathrm{rCl}$ of the ground water samples under study, where $(\mathrm{r}=\mathrm{mq} / \mathrm{L})$ for these parameters in each sample compared with that of the standard values of sea water as demonstrated by Abdel Moneim, A.A. (1998)

\section{3- Suitability of the ground water samples for irrigation and industrial purposes:}

Table (3) shows values of parameters that are typically used as indices for inferring suitability of ground water for irrigation and industrial uses.

Table (3). Parameters indicating suitability of the ground water samples for irrigation and industrial uses.

\begin{tabular}{ccccc}
\hline & \multicolumn{4}{c}{ Parameter } \\
\cline { 2 - 5 } Well site \& No. & $\begin{array}{c}\text { SAR } \\
(\mathrm{meq} / \mathrm{l})\end{array}$ & $\begin{array}{c}\text { RDS } \\
(\mathrm{Na} \%)\end{array}$ & $\begin{array}{c}\text { RSC } \\
(\mathrm{m}) \mathrm{ll})\end{array}$ & SI \\
\hline $\begin{array}{c}\text { Al-Durafi stadium } \\
\text { (Well No.1) }\end{array}$ & 0.57 & 9.0 & -12.54 & 0.3 \\
\hline $\begin{array}{c}\text { Shamlan area } \\
\text { (Well No.2) }\end{array}$ & 1.38 & 32.5 & -0.02 & -0.21 \\
\hline $\begin{array}{c}\text { Asser area } \\
\text { (Well No.3) }\end{array}$ & 4.87 & 70.8 & 2.31 & 0.35 \\
\hline $\begin{array}{c}\text { Adhban aeria } \\
\text { (Well No.4) }\end{array}$ & 2.17 & 48.2 & 1.41 & 0.08 \\
\hline $\begin{array}{c}\text { Al-tayseer } \\
\text { (Well No.5) }\end{array}$ & 4.05 & 66 & 1.66 & 0.6 \\
\hline $\begin{array}{c}22 \text { may area } \\
\text { (Well No.6) }\end{array}$ & 0.69 & 15.2 & -3.28 & 0.31 \\
\hline $\begin{array}{c}\text { Bin Maged } \\
\text { (Well No.7) }\end{array}$ & 9.26 & 90.9 & 1.26 & 0.21 \\
\hline $\begin{array}{c}\text { Alzubairy garden } \\
\text { (Well No.8) }\end{array}$ & 5.29 & 77.4 & 1.29 & 1.28 \\
\hline $\begin{array}{c}\text { Albaldiah area } \\
\text { (Well No.9) }\end{array}$ & 11.50 & 92.5 & 2.32 & 0.73 \\
\hline
\end{tabular}

Sodium Adsorption Ratio (SAR) $=\frac{\mathrm{Na}^{+}}{\sqrt{\frac{\left(\mathrm{Ca}+\mathrm{Mg}^{++}\right)}{2}}} \mathrm{meq} / \mathrm{L}$

Ratio of dissolved sodium (RDS) $\mathrm{Na} \%=\frac{\mathrm{Na}^{+}}{\mathrm{Na}^{+}+\mathrm{Ca}^{2+}+\mathrm{Mg}^{2+}+\mathrm{K}^{+}} \times$

Residual sodium carbonate $(\mathrm{RSC})=\left(\mathrm{CO}_{3}^{2-}+\mathrm{HCO}_{3}^{-}\right)-\left(\mathrm{Ca}^{2+}+\mathrm{Mg}^{2+}\right)$,

(-) Value indicates no residual carbonate, and (+) Value indicates presence of residual carbonate.

Saturation Index (SI) is $\mathbf{p H}_{\mathrm{c}}=\left(\mathrm{pk}_{2}-\mathrm{pk}_{\mathrm{s}}\right)+\mathrm{pCa}^{2+}+\mathrm{pAlk}$

(-) Value indicates suitability for industrial purposes, and (+) Value indicates unsuitability for industrial purposes.
Sodium adsorption ratio (SAR), ratio of dissolved sodium (RDS) as $\mathbf{N a \%}$, or residual sodium carbonate (RSC) might equally be used for calculating a value which can be utilized as an index of grounct an index of grou vation wation purposes (Shaki and Adeloye, 2006). All three parameters were employed in this study; however SAR is the most commonly one used for evaluating ground water suitability for irrigation purposes (Ayers and Westcot, 1985). As it can be noted from table (3), SAR values of samples drawn from wells no. (1, 2, 4, 5and 6) ranged from 0.5 to 4.05. Such values indicated that these wells water is considered as good for irrigation purposes at any types of soil (Soltan, 1998). SAR values of the water samples drawn from wells no. $(3,7,8$ and 9) ranged from 4.87 to 11.50 and this $(3,7,8$ and 9$)$ ranged from 4.87 to 11.50 and this may imply the presence of a hazard to soil and crop, when used such ground water source used for irrigation. That is because excessive sodium concentration in irrigation water would result in substantial decrease in soil permeability (Soltan, 1998; Shaki and Adeloye, 2006). This also can be supported through taking into consideration the RDS values of the water samples drawn from wells no. (3, 7,8 and 9) shown within the same towells no. (3, 7,8 and as proved that they all exced $70 \%$ ble, whe it was poved they all exceed $70 \%$ Na. Morcover, it is clear from table (3) that the se ground water samples had RSC indices of positive value, implying that the cumulative concentratio of the $\left(\mathrm{CO}_{3}{ }^{2-}\right.$ and $\left.\mathrm{HCO}_{3}^{-}\right)$is higher than the combined $\left(\mathrm{Ca}^{2+}\right.$ and $\left.\mathrm{Mg}^{2+}\right)$ concentration. This would indicate there is a residual carbonate to react with sodium, presenting sodium hazard to soil when irrigated with such water.

As for testing the ground water suitability of this study for industrial purposes, the saturation index (SI) was used to speculate the extent to which water flowing through pipes will precipitate or dissolve calcium carbonate. According to Rhades and Bernstein (1971), this index is defined as the actual $\mathrm{pH}$ of a water sample $(\mathrm{pH})$ minus the $\mathrm{pH}$ calculated, which the water would have equilibrium with calcium carbonate $\mathrm{pH}_{\mathrm{c}}$ as follows:

$$
\mathrm{pH}_{\mathrm{c}}=\left(\mathrm{pk}_{2}-\mathrm{pk}_{\mathrm{s}}\right)+\mathrm{pCa}^{2+}+\mathrm{pAlk}
$$

Where $\mathrm{pk}_{2}$ is the negative logarithms of the second dissociation constant of $\mathrm{H}_{2} \mathrm{CO}_{3}, \mathrm{pk}^{2}$ is the solubility product constant of calcium carbonate, $\mathrm{pCa}^{2}$ is the mod cons the equivalent concentration of $\mathrm{CO}_{3}^{2-}$ plus $\mathrm{HCO}_{3}$ If the saturation index is positive, $\mathrm{CaCO}_{3}$ will precipitate, but if it is negative, $\mathrm{CaCO}$ will dissolve. By applying this index to the data of the samples shown in table (3), it was fourd of wn from wells $0 .(1,3,4,5,6,7,8$ and 9 and 9) had positive values, while that of well no. (2) had negative value. Such finding exhibit tendency for a ground water samples, except that of well no. (2) to precipitate $\mathrm{CaCO}_{3}$ in pipes. Therefore, almos all ground water of wells used for this study appeared not to be suitable for industrial purposes.

\section{Conclusion}

Based on criteria limits specified in the standards of the WHO, and according to the standards of the Yemeni Guideline for drinking water quality, ground waters of all wells, except that of well no. (1), which belongs to $\boldsymbol{A L}$-Tahreer district, were considered suitable for drinking and domestic uses. Although ground water samples of this study were found to be good for irrigatio purposes at any types of soil, only that of well no. (2) was found to be suitable for industrial uses.

\section{REFERENCES}

[1] Abdel Moneim,A.A. (1998). Hydrogeology of the Nile basin Solag province, MSc. Thesis,Geol. Dept., Fac.Sci, Assuit Univ., Assiut Egypt.

[2] American Public Health Association, APHA, (1998). Standard methods for the Examination of water and wastewater $20^{\prime \prime}$ APHA, Washington, DC,USA.

[3] Ayers, R.S., Westcot, D.W., (1985). Water quality for agriculture. In: FAO Irrigation and Drainage paper 29 Rev. 1 , FAO, Rome.

[4] Chgue'-Goff, C., Rosen, M. R. and Eser, P., (1999). Sewage effluent discharge and geothermal input in natural wetland, Tongariro Delta, New Zealand. Ecological Eng., 12, 149 170.

[5] Davis, S.N. and De Wiest, R.J., (1967). Hydrogeology (2 ${ }^{\text {nd }}$ Edn) p.463. willey New York.

[6] Eaton, F.M., 1950. Significance of carbonate in irrigatio Wats. Soll Sci. 69, 123-133. .

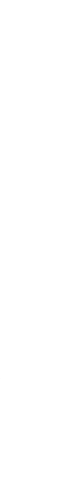


[8] Foppen, J. W. A., (2002). Impact of high-strength wastewater infiltration on groundwater quality and drinking water supply: the case of Sana'a, Yemen

[9] Foppen, J. W. A., Naaman, M., Schijven, J. F., (2005). Managing water under stress in Sana'a, Yemen. The Arabian Journal for Science \& Engineering, 30, (2C): 69 - 83.

[10] Klimentov, P.K., (1983). General hydrology (1 ${ }^{\text {st }}$ Edn),

pp.101- 112. Russian ends Moscow.

[11] Matthess, G. (1982). The properties of Ground water (1 ${ }^{\text {st }}$

Edn), John Wiley \& Sons, New York.

[12] Mattiesen, H., (2008). Detailed chemical analyses of groundwater as a tool for monitoring urban archaeological deposits: results from Bryggen in Gergen. J. Archaeological Science, 35, $1378-1388$.

[13] Rhades, J.D and Bernstein, L., (1971). Chemical, physical and biological characteristics of irrigation and soil water, In water and water pollution (Edited by Ciaccio, L.L.), chap.3. Marcel Dekker Inc., New York.

[14] Shaki, A. A. and Adeloye, A. J. (2006). Evaluation of quantity and quality of irrigation water at Gadowa irrigation project in Murzug basin, [15] Sultan, $1.193-201$.

[15] Sulten, M. E., (1998). Characterization, classification, and evaluation of some ground water samples in upper Egypt.

[16] WHO (World Health Organization), (2006). Guideline

ing water quality recommendation.

\section{OPTIMIZATION OF NMP EXTRACTION IN 1, 3-BUTADIENE PRODUCTION LINE}

H.R.Mortaheb ${ }^{*}$, M.Mafi $^{*}$, B.Mokhtarani ${ }^{*}$, K.Khosravi $^{* *}$, F.Mashkini * Faculty of Chemical Engineering \& Physical Chemistry

"Department of Analytical Chemistry
Chemistry \& Chemical Engineering Research Institute of Iran 25 Km. Karaj High way, Pajoohesh blvd.

Keywords: $N M P$, Extraction, $n$-heptane, Distillation
${ }^{\prime}$ To whom correspondence should be addressed, khosravik @ yahoo.com

Abstract: N-methylpyrrolidone is a powerful solvent for variety of chemical processes due to it vast chemical properties. It has been used in manufacturing processes of polymers, detergents, pharmaceuticals rubber and many more chemical substances. However, it creates large amoun of residue in some of these processes which has to be dealt with. Many well known methods such as BASF in rubber producing units have tried to regenerate the solvent at the end of each run, however, there is still discarding of large amount of residue containing NMP, which over time, could cause environmental concerns. In this study, we have tried to optimize regeneration of the NMP extraction from butadiene production. It is shown that at higher temperatures NMP is separated from the residue with close to $90 \%$ efficiency, and the solvent residue proved to be is separated from the residue with

\section{Introduction}

N-methylpyrrolidone is a weak base and is an aprotic solvent with low volatility and toxicity (1).It is a powerful solvent for a wide range of chemicals, and Due to its thermal stability and its relatively high dielectric constant, it is extensively used in polymer industies (2,3).Its numerous ly used in polym ind advantageous qualities such as being environmentally friendly substance, non-carcinogenicity, noncorrosiveness, and low solvent loss have given widespread use in pharmaceutical products(4), detergent industries, polymer and rubber producing plants $(5,6)$, and many more usages are being found everyday. $\mathrm{N}$-methylpyrrolidione is used in series of processes such as degassing, distillation, and solvent regeneration in rubber manufacturing as solvent for the extraction of 1,3 -butadiene due to its high merit as a solvent, with the extracta- bility of more than $99 \%$; later the NMP and the residue is discarded or managed in a biologically equipped industrial waste treatment units which itself requires extra process and financial resources $(5,6,7)$. Recently, however, efforts have been invested in reviewing and revising the curren method. Our goal in this study was to find a way to extract NMP from the discarding residue of 1,3-Butadiene line to a higher percentage.

\section{Experimental}

\section{Instruments and Reagents}

All chemicals Methanol, Benzene, Toluene, Chloroform, Carbon tetrachloride, Xylene, ethyl 